\title{
Święty taniec Wybranej: \\ Oblicza ekstazy i upojenia w sztuce współczesnej
}

\author{
Malgorzata Jankowska \\ Zakład Historii Sztuki Nowoczesnej \\ Uniwersytet Mikołaja Kopernika w Toruniu \\ Malgorzata.Jankowska@umk.pl
}

\begin{abstract}
Abstrakt
W historii tańca utwór Święto wiosny Igora Fiodorowicza Strawinskiego zajął szczególne miejsce jako skandaliczny i przełomowy. Jego najbardziej przejmującą częścią jest kończący libretto Wielki, święty taniec Wybranej/Ofiary, która tańczy na śmierć. Taniec Wybranej nie jest mową ciała wolnego, lecz koniecznością. Przeciwnie więc do koncepcji Friedricha Nietzschego taniec ofiary jest obdarzony „duchem ciężkości” jako wyrazem narzuconej woli.
\end{abstract}

Motyw „świętego tańca” powraca we współczesnych interpretacjach za każdym razem obarczony innym znaczeniem. Wychodząc od dzieła pierwotnego i koncentrując się na postaci Wybranej oraz charakterze pradawnego rytuału, omówione zostaną dzieła Piny Bausch, Katarzyny Kozyry oraz Klausa Obermaiera, by na ich podstawie wskazać w jaki sposób łączą się one lub odbiegają od pierwoworu. Istotne będzie również odniesienie do metafory tańca i pojęcia ekstazy, które wraz z utworami zmieniają znaczenia, przemieszczając się pomiędzy funkcją aktywnej mocy a siłą, powodującą zniewolenie.

Słowa kluczowe: Święto wiosny; Igor Fiodorowicz Strawiński; Nikołaj Konstantinowicz Roerich; Katarzyna Kozyra; Klaus Obermaier; Le Sacre du Printemps; Taniec Wybranej.

Taniec i ekstaza, rozumiane jako formy wypowiedzi, posiadają wspólne własności. Są nimi zapomnienie i oderwanie od świata materialnego, oraz wyjątkowa intensyfikacja emocji i ekspresji. Wznoszące się w tańcu ciało, podobnie jak ulatująca w przestrzeń świadomość mistyczek, szybuje poza normami i zakazami. U Friedricha Nietzschego taniec stanowi metaforę myśli, wyraz samorozwijającej się ruchliwości, ruchu ciała pozbawionego wulgarności, który umożliwia wyjście poza siebie. Alain Badiou pisał, iż w ujęciu niemieckiego filozofa taniec pozwala przemierzać świat „w swym powiązaniu z mocą i szaleństwem”, dlatego Zaratustra powie o sobie, że „ma stopy szalonego tancerza” (Badiou 2013: 234). Ekstaza natomiast, według francuskiego estetyka Jean-Noëla 
Vuarneta, ,potęguje moc działania”, można ją nazwać doświadczeniem poetyckim, spekulatywnym, erotycznym. Przekracza wszelkie zakazy w doświadczeniu szaleństwa, rozumianym jednak nie jako ,podróż przez czy w szaleństwo, lecz podróż wspomaganą przez nierozum“ (Vuarnet 2003: 22). Tak więc zarówno taniec, jak i ekstaza same w sobie stanowią moc aktywną, która pozwala ciału „oderwać się od siebie”. Egzemplifikacją tak ujmowanych tańca i ekstazy może być forma alegorycznego tańca śmierci, której źródła sięgają późnego średniowiecza. Danse macabre opisywano jako korowód połączonych ze sobą ciał żywych i martwych, podczas którego następuje moment oderwania ciała od swojego ziemskiego ciężaru i zapomnienie wszystkiego, co doczesne.

Obie formy wypowiedzi odnajdujemy w motywie Świętego tańca Wybranej z libretta Święto wiosny Igora Fiodorowicza Strawińskiego, który zarazem stanowi przekroczenie wolności przysługującej zapomnieniu i oderwaniu. Taniec Wybranej nie jest już mową ciała wolnego, nie dokonuje się również jako jego wola, lecz jako narzucona konieczność wymagająca posłuszeństwa i podporządkowania. Tym samym taniec i szaleństwo stają się przeciwieństwem idei wolności wewnątrz ciała, stanem ciała „uderzającego”, a nie „eterycznego", a więc przeciwieństwem tego co na temat tańca pisał Friedrich Nietzsche. Dla niemieckiego filozofa taniec był stanem pomiędzy rzeczywistością a wznoszeniem się w przestrzeń - metaforą najpełniejszej idei myślenia. „Uderzające” ciało Wybranej to ciało pozbawione tej funkcji, w swojej bezwolności i ciężarze, potwierdzające jego uległość i bezbronność wobec nakazu (Badiou 2013: 235).

W artykule przedstawię różne oblicza motywu Świętego Tańca Wybranej w realizacjach współczesnych artystów, wskazując na to, w jaki sposób zbliżają się lub odbiegają od pierwowzoru. Własności tańca i ekstazy posłużą mi jako ekran, na którym projektowane będą kolejne ich przemiany dokonywane w wybranych interpretacjach.

\section{Święto wiosny - Obrazy z życia dawnej Rusi w dwóch częściach}

Balet Święto wiosny - Obrazy z życia dawnej Rusi w dwóch częściach (skrócony tytuł oryginalny to z ros. Весна священная - Święta wiosna) powstał, jak miał powiedzieć Igor Fiodorowicz Strawiński, w następstwie snu o pogańskim rytuale, w którym mądrzy starcy siedzą w kole i obserwują przedśmiertny taniec dziewczyny, złożonej w ofierze bogu wiosny (Strawiński 2005: 76). Do tej inspiracji można dołączyć, zdaniem Modrisa Eksteinsa (1996: 53), wczesne wspomnienia kompozytora dotyczące wiosny i fascynację odrodzeniem. Wiadomo jednak, że Strawiński nie był ani wielbicielem tradycji pogańskich, ani zbyt wielkim admiratorem natury, nie bardzo dbał także o narodowy charakter swojej muzyki, choć stosował w utworach elementy zaczerpnięte $\mathrm{z}$ rodzimego folkloru (Erhardt 1978: 91). Kompozytor tworzył natomiast to, co było „w nim”, to, co wydawało mu się interesującym brzmieniem (Erhardt 1878: 95). Święta wiosna była więc efektem zarówno twórczego impulsu, jak i sprzyjających okoliczności. Były nimi zapotrzebowanie na rosyjską egzotykę, które w Europie i Stanach Zjednoczonych zdążył już rozbudzić Balet Rosyjski, powołany do życia i prowadzony przez Siergieja Pawłowicza Diagilewa, oraz 
zaproszenie do współpracy przy scenografii badacza i artysty Nikołaja Konstantinowicza Roericha, z którym Dagilew znał się z czasów „Świata Sztuki”, czasopisma i stowarzyszenia założonego przez rosyjskich modernistów. Roerich był nie tylko autorem tytułu, ale i współautorem libretta, autorem kostiumów i scenografii. To właśnie ten badacz i artysta jako jedyny z zespołu Strawiński - Roerich - Niżyński, pracującego nad Świętem wiosny, był szczerze oddany kulturowej tradycji Rusi. Badania Roericha z zakresu archeologii i etnografii skoncentrowane były na poszukiwaniu kulturowych korzeni, utrwalaniu i propagowaniu odległej historii i przywróceniu jej współczesnym. Efekty swoich badań i wypraw, także w Himalaje i do Indii, Roerich opracowywał w formie publikacji zarówno naukowych, jak i popularnonaukowych (wspomnienia z podróży, wiersze), wykorzystując je również w twórczości artystycznej. Jego zainteresowanie dawnymi kulturami: staroruską, tybetańską i indyjską oraz fascynacja naturą i nieograniczona wyobraźnia znajdowały odbicie w scenografiach, licznych studiach pejzażowych oraz scenach rodzajowych o tematyce mitologicznej i historycznej.

Pierwsze rozmowy na temat nowego utworu Igor Strawiński i Nikołaj Roerich podjęli w 1909 roku, określając jego temat i konstrukcję. Układ libretta miał powtarzać kolejne etapy archaicznego rytuału, zgodnie ze wskazaniem badacza. Podstawą do stworzenia scenografii był cykl obrazów olejnych ukazujących kolejne etapy rytuału, których część wykorzystano w przedstawieniu. W projektach kostiumów artysta bazował nie tyle na własnej wiedzy na temat staroruskiej i ludowej tradycji, co na twórczej inwencji. Kolorystyka i geometryczne dekoracje strojów znajdowały mimo to uzasadnienie zarówo w symbolice pierwotnych społeczności, jak i tradycji sztuki ludowej (Woodcock 2004).

Jako pierwsza powstała scena zatytułowana „Wielki, święty taniec”, która w ostatecznej wersji Święta wiosny kończyła libretto. To właśnie w niej pojawia się młoda dziewczyna - Wybrana, która w ofiarniczym tańcu tańczy tak długo, aż umrze. Rytuał, do jakiego odnosili się twórcy dzieła, to obrzęd, którego celem było ułagodzenie boga słońca i wiosny Jaryły/Jaruna (rdzeń jego imienia występuje w słowiańskiej nazwie ,jar” - „wiosna”, ale także „siła tkwiąca w młodości”). Aby odegnać zimę i przywołać wiosnę społeczność plemienna składała bóstwu ofiarę, która w przebłagalnym rytuale miała pośredniczyć jako akt komunikacji pomiędzy światem świętym a światem świeckim (Szyjewski 2004: 142). Tym samym śmierć miała w symboliczny sposób połączyć ofiarę z bóstwem (Gieysztor 1982: 109). Zgodnie z tym, co pisała badaczka Natalia Wielecka, istota obrzędów polegała „na wysyłaniu w określonym rytmie czasu posłańców w ów inny świat dla podtrzymania prawidłowego biegu rzeczy na ziemi”. Wysłanie było równoznaczne z unicestwieniem zwiastującym wiosenną odnowę. W szerszym ujęciu rytuał był wyrazem czci, szacunku i respektu dla wyższej mocy utożsamianej z naturą (za: Gieysztor 1982: 212). Nie zostało dowiedzione, mimo iż sugerowane, że ofiarą miała być młoda dziewczyna - Wybrana, która dobrowolnie oddawała się Jaryle. 


\section{Wybrana jako ofiara}

Dwuznaczność „Wielkiej Ofiary” (tytuł drugiej części libretta) zwraca uwagę na postać Wybranej. Podążając za etymologią słowa „Wybrana”, odnajdujemy w nim sens, który nadaje wybranej dziewczynie podwójną rolę. Wybrana (Wybranka) jest personifikacją panny młodej, tutaj w znaczeniu „Oblubienicy bóstwa”, o czym pisał sam Roerich: „W dowód wdzięczności społeczność składa w ofierze dziewicę jako pannę młodą Jaryle. Ona tańczy do śmierci w obecności szamanów, przepojona siłą duchową przodków plemienia", a jednocześnie przerażona jest tym, co ma nastąpić. W imię dobra ogółu przebłagalna ofiara musi ponieść śmierć, tylko wówczas nastąpi jej pojednanie z bóstwem. Powinna to uczynić dobrowolnie, poddając się transformującej sile rytuału, która połączy ją z bóstwem. Ekstaza i upojenie nie są jednak doświadczeniami starosłowiańskiej Wybranki znanej z wierzeń. Wątek Oblubienicy i zaślubin rozpowszechniony w tradycji chrześcijańskiej pod postacią motywu miłości Boga znany jest z przekazów mistyczek, swoistych chrześcijańskich „Wybranych”. W przypadku między innymi św. Teresy z Avili, wiara i oddanie Bogu nie miały granic. Jej „szaleńcza miłość” wynikała z pragnienia uzyskania stanu Jedności, dlatego święta nazywała siebie Oblubienicą, zdążającą ku zaślubinom z Bogiem-Oblubieńcem. Podczas długich przygotowań mistyczka opisywała drogę, jaką powinno się przebyć, by nastąpiło ,przemieniające zjednoczenie” możliwe jedynie poprzez śmierć, która byłaby, jak pisała św. Teresa, „szczęściem nieustannego rozkoszowania się jego obecnością” (św. Teresa z Avili, za: Vuarnet 2003: 109).

Oblubienica obrzędu w wersji przedstawionej przez Roericha, w przeciwieństwie do „Oblubienicy” chrześcijańskiej, zostaje wybrana przez społeczność w drodze eliminacji, a wybór - chociaż sprzeczny z jej wolą - musiał być przez nią zaakceptowany w imię dobra ogółu. Jak dowodzą Marcel Mauss i Henri Hubert, zgodnie z pierwotnymi rytuałami ofiara składana była poprzez ofiarnika, który dokładał wszelkich starań, aby zminimalizować ich kontakt. Rytuał przedstawiony przez Roericha i Strawińskiego byłby więc przykładem szczególnej władzy nad dziewczyną, władzy która pozbawiła ją woli i myśli. Śmierć zadana przez ofiarę samej sobie (taniec na śmierć) jako odstąpienie od aktu rytualnego zabójstwa, według badaczy znajduje swoje uzasadnienie w moralnym aspekcie aktu ofiary ${ }^{1}$. Samoofiarowanie się dziewczyny pozwala uniknąć ewentualnych konsekwencji, jakie mogą spaść na ofiarnika.

Innym wythumaczeniem motywu tańca na śmierć może być odniesienie do motywu Wybranej/Oblubienicy. W tradycji słowiańskiej to mąż wybiera sobie żonę, a ona musi podporządkować się jego decyzji. Poszczególne części tańca symbolicznie odnosiły się do kolejnych etapów zaślubin. W mitologii gesty i ruchy tańczących w postaci podrzucania, podskakiwania i kołysania miały na celu szeroko rozumiane wskrzeszenie magiczne, na

\footnotetext{
${ }^{1}$ Podczas rytuałów tego typu ważną ich część stanowiły działania przebłagalne i zapewniające ofiarę o czci i pozycji, jaką zajmuje. „Te środki ostrożności, przebłagania, oznaki czci mają na względzie dwa cele. Po pierwsze, wskazują na święty charakter żertwy; poprzez podkreślenie jej doskonałości i nazywanie własnością boga sprawia się, że taką w istocie się staje. Przede wszystkim jednak chodzi o skłonienie jej do łagodnego poddania się ofierze dla dobra ludzi i poniechania pośmiertnej zemsty" (Hubert i Mauss 2005: 41).
} 
przykład „ruszenie” roślinności, by ta rosła w górę, co stanowi symboliczne nawiązanie do płodzenia, którego celem jest powołanie nowego życia. Tego typu ruch czy taniec w obrzędowości słowiańskiej i nie tylko często był rozumiany jako symulacja porodu, który stanowił zwieńczenie zaślubin. Pewne odniesienia formalne, chociaż zupełnie odmienne w warstwie znaczeniowej, odnajdujemy w Nietzscheańskiej metaforze tańca jako wyraziciela idei ptaka i lotu. Badiou pisał o tańczącym ciele, które ,może właściwie tryskać, ponad ziemię, poza siebie”, paradoksalnie wskazując, że ,ziemia i powietrze wymieniają się pozycjami, przechodzą w siebie" (Badiou 2013: 234). Nie jest to jednak wyrazem woli natury, której celem jest prokreacja, a idei myślenia jako ruchu własnej intensywności, ,ruchliwości nie narzuconej, która sama się rozwija, jakby była ekspansją swego centrum" (Badiou 2013: 235). Chociaż u niemieckiego filozofa taniec pojawia się jako wyraz lekkości, to zarówno w koncepcji rytuału magicznego wskrzeszenia, jak i w ujęciu Niżyńskiego należy łączyć go raczej z ciężarem przypisywanym temu, co pozostaje poza naszą kontrolą (natura), lub temu, co zostaje nam narzucone. Niżyński nie analizował symbolicznych i historycznych znaczeń rytualnych obrzędów, nie poszukiwał dla nich ekwiwalentów w tanecznych figurach, wyczuwał jednak, że widoczną zmianę, wyzwalającą taniec $\mathrm{z}$ dotychczasowych norm, przyniesie dodanie mu ciężaru. Zabieg ten - zamierzenie czy nie - spowodował, że taniec Wybranej jest przeciwieństwem tańca, samą reprezentacją idei rozkazu, który z Wybranej czyni Ofiarę. Ciężar tańca Oblubienicy jest symbolem utraconego i podporządkowanego ciała-uderzającego, które zamiast wznosić się, opada bezbronne i wciskane w ziemię, która nie chce jej przyjąć. Nie ma tu radości ekstatycznych objawień mistyczek, jest rozpaczliwa bezradność dokonującego się unicestwienia.

Taniec Wybranej u Strawińskiego rozpoczyna się sceną wabienia Oblubieńca, przechodząc kolejno w akt konsekracji i poświęcenia. Zaślubiny będące zarazem seksualnym połączeniem stają się aktem ofiarowania i odkupienia (Hubert i Mauss 2005: 14). W ujęciu, w jakim przedstawiał rytuał Nikolaj Roerich, był on powtórzeniem rytuału płodności, który łączył się z doświadczeniem śmierci w ramach koncepcji świata podległemu wiecznemu obiegowi dialektycznej triady: życie - śmierć - życie. Utwór był również pochwałą natury reprezentowanej przez wiosnę-Jaryłę i równocześnie świadectwem podporządkowania człowieka, który jest jedynie wykonawcą jej woli. Porządek rytuału i sama jego konieczność dowodzą jednak istnienia zasad ustanowionych nie przez boskie, ale ludzkie prawo, które od ciała wymaga posłuszeństwa i milczenia. W tym układzie taniec Wybranej w okręgu nie może być tańcem przywołującym ukochanego, by połączyć się z nim zarówno w sensie symbolicznym, jak i fizycznym. To przede wszystkim taniec śmierci przekupionej obietnicą pojednania dziewczyny z bóstwem, która bardziej niż oczekiwaniem na wybranego wstrząsana jest wątpliwościami i strachem. Okrąg, symbolizujący magiczną figurę wskazującą na boską moc, staje się więc miejscem jej uwięzienia i poniżenia.

Jako naukowiec i badacz Roerich, a wraz z nim Strawiński i Niżyński nie zajmowali się jednak kwestiami etycznymi, każdy rozumiał Święto wiosny na swój sposób: Roerich jako dowód jego szacunku dla dawnej kultury Słowian, Strawiński jako muzykę, jaką czuł, natomiast dla Niżyńskiego był to hołd ku czci samego tańca - sztuki wymagającej 
zaangażowania i poświęcenia. Kobieca ofiara, zarówno w perspektywie historycznej, jak i kulturowej, była dla nich czymś naturalnym i oczywistym, zgodnym z biologicznym rytmem i przypisywaną jej społeczną rolą.

To właśnie końcowa scena Święta wiosny i konwulsyjny, wstrząsający taniec Wybranej są najczęściej przywoływanym motywem współczesnych interpretacji utworu.

\section{Latać i mówić}

Wyraźnie krytyczną odpowiedzią na dwuznaczną rolę Wybranej z utworu Strawińskiego pokazał spektakl Frühlingsopfer (Ofiara wiosny) Piny Bausch (1975), akcentując pozycję i znaczenie kobiety. Niemiecka tancerka i choreografka wyróżniła ofiarniczą pozycję kobiety, lecz nie w sensie, w jakim widział ją Roerich, czyli kobiety, która przyjmuje narzuconą jej rolę, rozumiejąc swój gest jako wyraz szacunku dla wyższej mocy, a zarazem powrót do korzeni swojego biologicznego przeznaczenia. Co ciekawe w choreografii Niżyńskiego Taniec Wybranej wydaje się tak samo entuzjastyczny, jak rozpaczliwy, co wskazuje równocześnie nie tylko na opętańcze zanurzenie w rytuale, ale i strach przed tym, co ma nastąpić. U Piny Bausch Ofiara jest realna i pozbawiona symbolicznych oznaczeń oraz rytualnego wywyższenia, w postaci wyznaczonego przez okrąg rytualnego miejsca połączenia. Choreografia nie idealizowała ciała, które u Strawińskiego przyozdabiała szata malowana w boskie symbole, jakby rehabilitując okrutność rytuału. U Bausch było to ciało kobiety zgwałconej - cierpiącej, wyczerpanej i poniżonej - ciało ludzkie, nie zaś przeznaczone dla boga. Solowy taniec Ofiary u Bausch każe wrócić do układu pierwotnego baletu i zobaczyć go w tej perspektywie nie jako akt pojednania, ale dowód dokonanej krzywdy, lament i rozpaczliwa próba odtworzenia przeżytego dramatu. To nie jest taniec kobiety „szybującej”, lecz tej, która oskarża o odebranie głosu i lekkości, dając temu świadectwo przymuszonym i poddanym ciałem. Taniec Wybranej to rozdzierająca scena cierpienia i kary, jaką ofiara w autodestrukcyjnych gestach wymierza samej sobie. Tę autodestrukcyjność widzimy również w układzie Niżyńskiego, mimo iż wiemy, że były one raczej wyrafinowaną kwintesencją poszukiwań i eksperymentów choreografa, który w „prymitywnej energii” gestów i kroków widział ostateczny sposób zerwania z tańcem klasycznym. Odrzucenie przez Bausch antropologicznego kontekstu jest gestem znaczącym, krytycznym wobec patriarchalnie skonstruowanej kultury, której dowodem jest Święto wiosny.

\section{Taniec śmierci}

W sztuce współczesnej odnajdujemy dalsze przykłady interpretacji Święta wiosny. Katarzyna Kozyra zaprezentowała pierwszą wersję Święta (1999) w postaci wideoinstalacji (drugą wersję pracy pokazała w Zachęcie w 2002 roku), a kilka lat później Klaus Obermaier wystawił Sacre du Printemps (2006/2007). W obu dziełach artyści odnoszą się 
bezpośrednio do ostatniej sceny libretta - „Wielkiego tańca Wybranej”, akcentując zupełnie inne elementy i motywy, przy czym dokonują kolejnych przewartościowań tej samej, głównej figury dramatu w kontekście zajmującej ich problematyki. Tym, co pozostaje z pierwotnego utworu, jest konwulsyjność i ekstatyczność, które sprawiają, że ten zaklęty taniec wprawia w trans, nie przynosząc jednak upojenia. W obu przypadkach mamy więc do czynienia z rodzajem mistycznego rytuału, tyle tylko, że w przypadku Kozyry będzie on odnosił się do starości i śmierci, a w przypadku Obermaiera do świata przyszłości, w którym to, co dawne, stapia się z tym, co współczesne.

Katarzyna Kozyra bazowała na rekonstrukcji Święta wiosny dokonanego przez Millicent Hodson i Kenneth Archer (1985). Motywem, który zafascynował artystkę, był fragment kończący libretto, w którym mechaniczność i hipnotyzujące gesty tancerzy, powtarzane w różnych częściach utworu, w scenie „tańca na śmierć” stanowią moment kulminacyjny. Tym, co szczególnie zaintrygowało Kozyrę, była konwulsyjność oraz nieprawdopodobny sprzeciw wobec praw własnej cielesności wyrażony gestami i ruchem tancerzy. Wysiłek, jaki tancerze musieli włożyć w układ opracowany przez Niżyńskiego, był ogromny, nie tylko z powodu jego skomplikowania, ale również niekonwencjonalności ruchów, do których tancerze nie byli przyzwyczajeni zarówno w momencie pierwszego wystawienia baletu, jak i podczas odtworzenia jego układu.

„Taniec Wybranej” składa się z serii powtarzanych podskoków, przeciwstawnych układów korpusu, głowy i rąk, nieporadnych, prawie niezgrabnych wymachów. Ciało wydaje się w nich obojętne na grawitację, ,jakby wbrew sile ciążenia”, zatrzymując się w powietrzu i z powrotem opadając na ziemię z jeszcze większym trudem (Kozyra 2010: 146). To, czego tancerze uczyli się z taką pieczołowitością: lekkości i gracji, podczas prób do Święta wiosny musiało zostać zapomniane na rzecz „nabywania” ciężaru, które uwidacznia się w charakterystycznych układach nóg, stawaniu na całych stopach, których czubki skierowane były do wewnątrz (Kochno 1970: 88). Ich ciała musiały być ciężkie i posłuszne rozkazom, tresowane aż do osiągnięcia zamierzonego efektu podążania w głąb. Bogate i krępujące kostiumy Roericha oraz dominująca nad całością scenografia triumfującej nad człowiekiem przyrody powodowały, że utwór zyskiwał dodatkowy wymiar jako gigantyczny hołd dla monumentalnej i nieprzeniknionej siły natury, która całkowicie panuje nad ograniczonym swoją fizycznością człowiekiem.

U Kozyry nie ma Wybranej w sensie, w jakim występowała ona w pierwotnym utworze. Jej taniec został zmultiplikowany i rozproszony na kilku tancerzy, odtwarzających układ tańca w okręgach. Tancerzami u Kozyry są starzy ludzie, którzy wbrew własnym możliwościom wykonują skomplikowane ruchy wymyślone przez Niżyńskiego. Jest to możliwe dzięki animacji poklatkowej, za sprawą której gesty wykonywane przez leżących modeli zostały ożywione. Taki sposób rejestracji wzmógł wrażenie bezwolności, co widać w szarpanych, wymuszanych gestach i ruchach. Specyficzny efekt marionetki stanowi doskonałą przenośnię władzy nad ciałem, co zresztą pokrywa się z efektem pierwowzoru. Ofiara Wybranej z dzieła Strawińskiego zostaje złożona za sprawą decyzji ogółu, natomiast w dziele Kozyry to artystka narzuca tancerzom swoją wolę: 
Na moim filmie pokazuję bezwolne ciało. Moi starcy to bierne ciała, kukły, które wyginam. Robię, co chcę, nie oprą mi się, używam ich ciał i łamię przeświadczenie, że człowiek jest istotą samostanowiącą i samodecydującą o sobie. Przecież ten ktoś jest kierowany. Tu jest tylko ciało, ciało pozbawione woli. A mimo to porusza się (Kozyra 2010: 147).

Wyeksponowana u Kozyry starość, nie po raz pierwszy obecna w jej twórczości, podkreślona nagością modeli, w pierwszym odczuciu - jak pisała Maria Poprzęcka - wywołuje w nas uczucie „groteski”, które następnie przechodzi w fascynację precyzją i zbieżnością z układem pierwotnym (Poprzęcka 2014). Wyczuwalny jest również efekt podporządkowania i nakazu, który za sprawą technologii porusza niezdolne ciała, wymuszając ich ekstatyczny taniec.

W układzie dzieła artystka zachowała ogólny charakter układu choreografii Niżyńskiego. W siedmiokanałowej instalacji projekcje odbywają się na ekranach zawieszonych w przestrzeni tak, by tworzyły one kształt dwóch wpisanych w siebie okręgów. W scenografii Roericha i choreografii Niżyńskiego układ okręgów był istotny dla znaczenia rytuału, bo ich symbolika odnosiła się do przestrzeni życia i śmierci oraz podziału na sfery: ziemską i boską. W dawnych obrzędach koło miało znaczenie magiczne, stanowiąc ochronę przedmiotu czy osoby znajdującej się w jego wnętrzu, było również konieczne dla zamknięcia, mocy podczas wykonywania rytuału. W instalacji Kozyry układ ekranów pozwala na swobodne przemieszczanie się widzów w przestrzeni okręgów, co umownie włącza ich w monumentalny spektakl-rytuał. Tańczący w okręgach starzy ludzie odwołują się również do ikonograficznego motywu tańca śmierci. Triada: życie - śmierć - życie, o której mówił Roerich, nadawała życiu miejsce nadrzędne, a śmierć stanowiła zawsze impuls do jego narodzin. Akt ofiarny ujęty w ramy kultury patriarchalnej, jak pisze Anna Markowska, należy jednak do świata kobiecego (Markowska 2003: 150-158) i zwiastuje nadchodzącą śmierć, poświęcenie, a nawet miłość. U Strawińskiego ofiarą jest młoda kobieta, u Kozyry wiek i płeć przestają mieć znaczenie. Za sprawą charakteryzacji ulega ona zmianie, a Wybrana jest zarówno kobietą, jak i mężczyzną. Ciała tańczą w pustce, w nieustannym upadaniu i podnoszeniu się, jakby wybiegając na spotkanie ze śmiercią.

Tańczący korowód Kozyry dedykowany jest temu, co nieuchronne, i nawet technologia nie jest w stanie odwrócić procesu umierania. Totentanz odbywa się w „,pustce”, w której ciała tancerzy dzięki technice animacji mogą oderwać się od ziemi, poruszając się w taki sposób, jaki w rzeczywistości nie byłby możliwy. A jednak modele, pomimo że pozornie pozbawieni są oparcia, nie osiągają w pełni stanu nieważkości, o jakim mówiła Kozyra. Ich nagie, stare ciała pozostają nieznośnie ciężkie i niezgrabne, znacznie bardziej niż owinięte w obszerne kostiumy ciała tancerzy z pierwotnej inscenizacji. Ich ciężar boleśnie wzmacnia animacja, która w zaskakujący sposób doskonale imituje rozpaczliwe i ekstatyczne wymachy rąk i nóg oraz wyczekujące drżenie Wybranej Niżyńskiego. Eteryczne ciało tańca zostaje u Kozyry zastąpione dosłownie i w przenośni ciałem ,uderzającym” i posłusznym. To już nie taniec, lecz rodzaj niezwykłego kręgu ciał zależnych i podporządkowanych i - zgodnie z tym, co mówiła artystka - raczej trupów niż ludzi. W przedstawieniach motywu tańca śmierci tańczą zazwyczaj zmarli, wprowadzony przez Kozyrę układ byłby więc połączeniem motywu śmierci i memento mori, w którym zarówno żywi, jak i zmarli spotykają się w tańcu. 


\section{Upojenie i rozpuszczenie}

W roku 2007 Klaus Obermaier zaprezentował publiczności interaktywny spektakl 3D, opracowany wspólnie z zespołem Ars Electronica Futurelab z Linz. Autriacki artysta, reżyser, choreograf i kompozytor w Le Sacre du Printemps skoncentrował się na „Tańcu Wybranej”. W odróżnieniu od dzieła Kozyry Obermaier kreuje taniec na nowo, nie unikając jednak dalekich, lecz rozpoznawalnych, analogii do ekstatycznych ruchów, powtórzeń i dynamicznych gestów Wybranej Niżyńskiego. W spektaklu Obermaiera jedyną postacią inscenizacji jest właśnie ona i jej święty taniec, który rozgrywa się niejako na bocznej scenie, bez rekwizytów i wyraźnie określonego kostiumu. Dopiero za sprawą technologicznej transformacji w wirtualny obraz Wybrana pojawia się na głównym, umieszczonym centralnie wobec widowni ekranie, zanurzona w wirtualnym świecie. Odbywający się w rzeczywistości nagi taniec Wybranej powtarza pierwotną kolejność „Tańca Wybranej” Niżyńskiego, przechodząc od euforii, poprzez strach, rezygnację, do ekstatycznej walki ze śmiercią w końcowej scenie. Jednak kompletność doznawanych stanów możliwa jest dopiero za sprawą mikrofonów, kamer, oprogramowania oraz „stereoskopowej" projekcji, które stapiają ze sobą elementy rzeczywistej muzyki i tańca z tym, co wirtualne - tego, co biologiczne, z tym, co technologiczne. Wyprodukowany na bazie realnych, lecz w swym znaczeniu ,abstrakcyjnych” mediów: tańca i muzyki, świat wirtualny staje się światem Wybranej. Ona sama nie jest dłużej ofiarą ziemskich pragnień i obaw ani pośredniczką pomiędzy światem ludzkim i boskim, w ostateczności także nie umiera, lecz - jak tłumaczy artysta - po prostu „zanurza” się w „wirtualności”, by połączyć, stopić się z muzyką i przestrzenią. Ofiara jest odpowiednikiem stanu „poświęcenia się" niepewnej przyszłości i metaforą wiecznego szczęścia i wybawienia, jakie oferują nam współczesne technologie i stare religie (Obermaier: 2006).

W wirtualnym świecie Wybrana przechodzi wielokrotną transformację, rozpuszczając się w wirtualności. Stany przejściowe, jakie przybiera obraz jej ciała, oglądany przez widzów wyposażonych w okulary 3D, paradoksalnie przypominają miejscami formy biologiczne. Ciało rośnie i pączkuje, nabierając kształtu embrionu, powoli wzrasta, by nagle przekształcić się w coś na kształt rośliny. Fragmenty ciała Wybranej przedłużają się w długie pędy, aby następnie rozpaść się na ,las” zmultiplikowanych rąk, nóg czy palców. Charakter tych transformacji bliższy jest specyfice języka informatyki niż natury, lecz nie da się wyeliminować podskórnej bliskości kobiecego żywiołu, tak często utożsamianego z tym, co chtoniczne. Znaczenie natury, które podkreślał Roerich, powraca u Klausa Obermaiera poprzez przemianę kobiety $\mathrm{w}$ roślinę. $\mathrm{W}$ wirtualnej przestrzeni pojawiają się także inne elementy, które odnoszą się do pierwotnej wersji utworu. Widać to wyraźnie w scenie początkowej, w której Wybrana przygotowuje dla siebie miejsce pojednania, kreśląc w powietrzu znaki, zjawiające się jako wirujące w okręgu znaki słowiańskiej głagolicy, przekształcając się z czasem w dendryczne komórkowe sieci. Z kolei w scenie końcowej, podczas ekstatycznej walki o życie, następuje rozpuszczenie Wybranej w cybernetycznym świecie, czy raczej jej zakodowanie w bazie danych, naśladujące akt konsekracji. Przejście od ciężaru do lekkości gwarantuje w tym układzie spełnienie marzeń o nieśmiertelności i życiu w alternatywnym świecie. 


\section{Podsumowanie}

„Taniec Wybranej” w utworze Strawińskiego wskazuje na doniosłą rolę OblubienicyOfiary, której poświęcenie łączy się ze społecznym nakazem podporządkowania. W jej szalonym, ekstatycznym tańcu nie odnajdziemy radości i szczęśliwej pokory, wynikających z dobrowolnego wyboru, lecz raczej strach i upokorzenie wobec tego, co zostało dla niej wybrane. Doświadczenie Wybranej bliskie jest ofiarniczej ekstazie, o której Vuarnet pisał, że jest „drogą męczenniczek nękanych halucynacjami ukrzyżowania, drogą milczących i boleściwych: torturowanych, noszących stygmaty, obłożnie chorych... Drogą mrocznych cierpień i okrutnych wyobrażeń” (Vuarnet 2003: 16). Niezgrabnym, ciężkim tańcem Wybrana daje milczące świadectwo dokonanego nadużycia, wskazując, że sakralny akt pojednania dokonuje się poprzez okrutną zbrodnię. Współczesna interpretacja Świętej wiosny Piny Bausch przywraca kobiecie prawo do mówienia i ekstazy. Ona to ona, jak pisała Hélène Cixous, ,po to, by wszystko znieść, rozbić na kawałki podstawy obecnych instytucji, wysadzić w powietrze prawo" (Cixous 1993: 160). Taniec rozumiany jako forma wypowiedzi, a więc jako pewnego rodzaju język, stanowi w tym kontekście moment uwolnienia, nieunikniony wybuch, eksplozję emocji i przeżyć, oskarżając patriarchalną władzę i jej społeczne przyzwolenie.

W interpretacjach artystów Katarzyny Kozyry i Klausa Obermaiera motyw ekstazy pojawia się w zupełnie innym znaczeniu. Postać Oblubienicy/Wybranej uzyskuje nowe wcielenie. W pierwszym wypadku możemy mówić o ekstatycznej wizji śmierci, obrazującej to, co nieuniknione. W przypadku spektaklu Obermaiera ekstatyczność powraca ku temu, co kobiece, chociaż nie to wydaje się w tej interpretacji najważniejsze. Ekstaza tańczącej wyraża czystą obecność przechodzącego transformację ciała, które ulega rozproszeniu, odrywając się od tego, co realne. Taniec, podobnie jak ekstaza, jest formą indywidualnej ekspresji, ale i działaniem, które mimo iż cielesne, wymaga szczególnej kondycji umysłu. Wybrana ze Święta wiosny chociaż tańczy, jest już martwa, i właśnie ten paradoks wydaje się szczególnie intrygujący dla sztuki współczesnej. Przedstawione przykłady interpretacji utworu Strawińskiego poszukują własnego sposobu na jego zrozumienie i chociaż gubią pierwotny sens, wskazują na inne istotne problemy.

\section{Bibliografia}

Cixous, H. 1993. Śmiech Meduzy. Teksty Drugie: Teoria literatury, krytyka, interpretacja, 4-6: $147-166$.

Eksteins, M. 1996. Święto wiosny. Wielka wojna i narodziny nowego wieku. Warszawa: Państwowy Instytu Wydawniczy.

Erhardt, I. 1978. Igor Strawiński. Warszawa: Państwowy Instytu Wydawniczy.

Gieysztor, A. 1982. Mitologia Stowian. Warszawa: Wydawnictwa Artystyczne i Filmowe.

Hubert, H. i Mauss, M. 2005. Esej o naturze i funkcji ofiary. Kraków: Zakład Wydawniczy Nomos. Kochno, G. 1970. Diaghilev and the Ballets Russes. New York: Harper \& Row Publishers. 
Kozyra, K. 2010. Casting. Warszawa: Zachęta Narodowa Galeria Sztuki: 146-149.

Markowska, A. 2003. Definiowanie sztuki - objaśnianie świata. Katowice: Wydawnictwo Uniwersytetu Śląskiego.

Obermaier, K. 2006. Le Sacre du Printemps. Igor Stravinsky. Źródło: http://www.exile.at/sacre/project.html, 01.03.2016.

Poprzęcka, M. 2015. „Święto wiosny” Katarzyny Kozyry. Źródło: http://www.wysokieobcasy.pl/wysokie-obcasy/1,96856,781600.html, 10.06.2015.

Rierich, N. K. 1995. Зарождение легенд / Листы дневника. Źródło: http://etikavomne.agni-age.net/gallery/content/477.htm, 10.06.2015.

Strawiński, I. 2005. Хроника моей жизни. Москва: Издательский дом „Композитор”.

Szyjewski, A. 2004. Religia Stowian. Kraków: Wydawnictwo WAM.

Vuarnet J. N. 2003. Ekstazy Kobiece. Gdańsk: Wydawnictwo słowo/obraz terytoria.

Woodcock, S. 2004. Costume from The Rite of Spring. Źródło:

http://www.vam.ac.uk/content/articles/c/costume-from-the-rite-of-spring/, 01.03.2016.

\title{
Materiały filmowe z K. Kozyra, Święto Wiosny, K.Obermaier, Le Sacre du Printemps:
}

http://artmuseum.pl/pl/filmoteka/praca/kozyra-katarzyna-swieto-wiosny

https://www.youtube.com/watch?v=ZQ2Vnv1Fm_o

\begin{abstract}
In the article I present different faces of the theme of the Holy Dance in the realizations of contemporary artists, indicating how they approach or deviate from the original. The features of dance and ecstasy will serve as a screen on which their subsequent transformations occurring in selected interpretations will be performed.
\end{abstract}

Keywords: The Rite of Spring; Igor Fiodorowicz Stravinsky; Nikołaj Konstantinowicz Roerich; Katarzyna Kozyra; Klaus Obermaier; Le Sacre du Printemps; The Chosen One's Dance. 